\title{
UNCED - Fragen für die Schweiz
}

La CNUED, les enjeux pour la Suisse

Alain Clerc

\section{OpenEdition}

\section{Journals}

Édition électronique

URL : http://journals.openedition.org/sjep/1392

DOI : $10.4000 /$ sjep.1392

ISSN : 1663-9677

\section{Éditeur}

Institut de hautes études internationales et du développement

\section{Édition imprimée}

Date de publication : 1 janvier 1992

Pagination : 205-212

ISSN : 1660-5926

\section{Référence électronique}

Alain Clerc, "UNCED - Fragen für die Schweiz », Schweizerisches Jahrbuch für Entwicklungspolitik [En ligne], 11 | 1992, mis en ligne le 19 mai 2013, consulté le 08 septembre 2020. URL : http:// journals.openedition.org/sjep/1392 ; DOI : https://doi.org/10.4000/sjep.1392

Ce document a été généré automatiquement le 8 septembre 2020.

(c) The Graduate Institute 


\section{UNCED - Fragen für die Schweiz}

La CNUED, les enjeux pour la Suisse

\section{Alain Clerc}

\section{NOTE DE L'ÉDITEUR}

Volltext auf Französisch in Annuaire suisse de politique de développement: „La CNUED, les enjeux pour la Suisse", http://aspd.revues.org/1565. 